\title{
QUANTITATIVE ANALYSIS OF ABATTOIR SLAUGHTERING OF ANIMALS IN AKWA IBOM STATE, NIGERIA
}

\author{
Opara, M.N., Ukpong, U.M. And Okoli, I.C.
}

\begin{abstract}
Abattoir survey was conducted to determine the trends, volume and value of food animals slaughtered in twenty local government areas of Akwa Ibom state, Nigeria from 1999 to 2002. A total of 151,303 animals comprising of 38,946 (25.7\%) cattle; 39,392 (26\%) goats; 11,758 (7.8\%) sheep; 24,449 (16.2\%) pigs, and 36,758 (24.3\%) dogs were slaughtered in the state during the period under review. Male/female ratios of 3.1:1, 3:1, 2.7:1, 2.7:1, and 3:1 were obtained for cattle, goats, sheep, pigs and dogs, respectively. Findings revealed that $32.8 \%$ of the animals were slaughtered in 1999 while 37.9\% were slaughtered in 2000. However a lower percentage (12.8\%) was slaughtered in 2001. Three peak periods of demand for cattle were in 1999, 2000 and 2002; two for goats: 1999 and 2000: one for sheep: 2000; two for pigs: 1999 and 2000, and two for dogs: 1999 and 2000. Meat inspection activities in the state translated to a revenue of 3.07 million Naira within the period of study, although this can be improved. It was concluded that cattle, goats and pigs are the most popular food animals in the state with dog meat providing a good alternative source of animal protein requirements for the populace.
\end{abstract}

Keywords: Abattoir, Akwa Ibom, Returns, Local government

\section{INTRODUCTION}

Ruminant livestock dominate the population of meat animals slaughtered in abattoirs in southern Nigeria (Ogunyemi, 1982). Meat products from these food animals supply the greater amount of animal protein in these areas, although a lot of people derive their protein largely from vegetable sources $(\mathrm{Mba}, 1983)$. In Nigeria, slaughtering is done either in modern abattoirs, municipal slaughter halls or community slaughter slabs. Data from these slaughter points have been utilized to improve slaughter facilities thereby leading to the production of wholesome products with good keeping qualities from a good population of food animals. In addition, information generated from the abattoirs are important in the formulation of effective control strategies against some notable diseases (Aganga, 1983; Gracey, 1985; Ogundipe et al., 1989; Wehke et al., 1992; Okoli, 2001) of livestock. Beef constitutes the major source of animal protein for the majority of Nigerians (Ojo and Ema, 1984). However, meat from sheep, goats and pigs are equally important sources of protein (Momoh et al., 1998; Okoli et al., 2002). Akwa Ibom state in the southeastern region of the country is an elitist state where meat is highly appreciated at every meal (Umoh et al., 1993). Although thousands of animals are slaughtered in the state each year no proper analysis of abattoir records has been carried out. The present study was therefore designed to determine the trends in abattoir slaughtering of animals in Akwa Ibom state, the volume and value of slaughter.

\section{METHODOLOGY}

Data on the number of cattle, sheep, goats, pigs and dogs slaughtered for consumption in Akwa Ibom State, Nigeria was monitored for four years (1999-2002) using meat inspection records collected from the public health unit of the Federal Livestock Department (FLD) Akwa Ibom State zonal office. Meat inspection records for the state are usually generated through the inspection activities of the state Veterinary personnel who cover all the official designated slaughter points in the different local government areas (LGA). Data from the 
LGAs are pooled at the state Veterinary headquarters at the end of each month and then resubmitted to the FLD zonal office as monthly meat inspection report. Available data contained slaughter figures from 20 local government areas of the state for the period of study which were further analyzed using simple averages, percentages, ratios and graph. Sexes and trends of the animals slaughtered were also noted.

\section{RESULTS}

The slaughter figures of cattle, goats, sheep, pigs and dogs from twenty local government areas of Akwa Ibom state (1999-2002) are presented in Table 1. A total of 151,303 animals were reported to have been slaughtered at the 20 LGAs. Of these are cattle 38,946 (25.7\%), goats 39,392 (26\%), sheep 11,758 (7.8\%), pigs 24,449 (16.2\%), and dogs $36,758(24.3 \%)$. These gave mean slaughter values of 1,947.3, 1,969, 587.9, 1,222.5 and 1,837.9 respectively. Trends across the LGAs show that 54,830 (36.2\%) animals were slaughtered in Uyo representing more than thirty fold increase over the lowest slaughter figure $1,784(1.2 \%)$ from Mbo. Among the species of animals slaughtered at the LGAs within the study period, the largest number of cattle $21,826(56.0 \%)$ were slaughtered in Uyo followed by $3960(10.2 \%)$ from Ikot Ekpene. The least figures for cattle were returned from Okobo $12(0.03 \%)$ and Mbo $11(0.03 \%)$. Comparatively, the highest returns for goats slaughtered in the LGAs were from Uyo, 13858 (35.2\%), Ikot Ekpene, 4199 (10.7\%), Eket 3473 (8.8\%), Abak 2301 (5.8\%), Uruan 2174 Oron 2158, each recording 5.5\%. The least slaughter figures for goats were recorded from Onna, Ukanafun, and Okobo which stood as $287(0.7 \%), 339(0.9 \%), 346(0.9 \%)$, respectively.

The highest number of sheep were slaughtered in Uyo 2133 (18.1\%), Ikot Abasi 814 (6.9\%), Ikot Ekpene $789(6.7 \%)$ and Eket 766 (6.5\%) while the lowest figures were recorded from Mkpat Enin 368 (3.1\%), Ikono 379 (3.2\%) and Uquo Ibeno 382 (3.2\%). From the LGAs, pigs were slaughtered mostly at Uyo, Ikot Ekpene, Abak and Eket which recorded total figures of $5919(24.2 \%), 1796(7.3 \%), 1717(7.0 \%)$ and $1714(7.0 \%)$ respectively, while the least slaughter figures were from Mbo 376 (1.5\%), Ekpe Atai 409 (1.7\%) and Okobo 428 (1.8\%). Uyo recorded the highest slaughter figure for dogs consumed in Akwa Ibom state. The figure recorded was 11,094 (30.2\%) followed by Uruan 3320 (9.0\%), Abak 2301 (6.3\%) and Ikot Ekpene 2199 (6.0\%). The lowest returns for dogs were posted from Mbo 538 $(1.5 \%)$, Ukanafun $668(1.8 \%)$. Overall, the $7.8 \%$ of sheep from the LGAs within the study period is about a third of the number of goats, cattle and dogs and a half of the pigs slaughtered.

Analysis of sex related differences in slaughter figures (Table 2) shows that during the study period, $29,533(75.8 \%)$ of the cattle slaughtered were males while $24.2 \%$ were females giving a sex ratio of 3.1:1. Similarly, a ratio of 3:1 was obtained for bucks and does, 2.7:1 for rams and ewes, while 2.7:1 was obtained for male and female pigs slaughtered. In the same vein, the ratio of male to female dogs slaughtered across the LGAs of Akwa Ibom state during the study period was 3:1. Information on breed and ages of the slaughtered animals were lacking from the records analyzed.

Table 3 shows the overall slaughter figures of animals from Local government areas of Akwa Ibom state from 1999-2002. Out of the 151,303 animals slaughtered, 57,411 (37.9\%) of them were in 2000 while 1999, 2002 and 2001 had $32.8 \%, 16.5 \%$ and $12.8 \%$, respectively. The highest figure of cattle was slaughtered in the year 2001 which recorded $13,645(35 \%)$, followed by 2000 and 1999 which recorded 12,378 (31.8\%) and 10,706 $(27.5 \%)$ respectively. The year 2001 witnessed the least slaughter figure $2,217(5.7 \%)$ of cattle within the study period. Also the records for goats shows that 15,240 (38.7\%) of them were slaughtered in 2000 while 14,171 (36\%) and 5,779 (14.7\%)were recorded in 1999 and 
2001 respectively. Four thousand two hundred and two (10.7\%) goats were equally slaughtered in the year 2002.

The highest slaughter figure for sheep was obtained in 2000 which recorded 7,343 (62.5\%), 1,638 (13.9\%), $1605(13.7 \%)$ and 1,172 (10.0\%) for 1999, 2001 and 2002 respectively. Similarly, majority of the pigs 9910 (40.5\%) were slaughtered in 2000 and $8,598(35.2 \%)$ in 1999. Again, the least slaughter figure of 2,464 (10.1\%) for pigs was obtained in the year 2002. The record for slaughtered dogs shows that 14,578 (39.7\%) of them were in 1999, while 12,540 (34.1\%) was obtained in 2000. The lowest slaughter figure of $3,423(9.3 \%)$ for dogs was received in the year 2002. At the prevailing meat inspection fee of $\$ 50.00$ per head of cattle and $\$ 10.00$ for each of the other animals, a total revenue of $\$ 3,070,870.00$ was realized from the slaughtering of these animals during the period under review. Of this amount, the slaughtering of cattle accrued $\$ 1,947,300.00$, while goats, sheep, pigs and dogs gave $\$ 393,920, \$ 117,580, \$ 244,490$ and $\$ 367,580$ respectively.

Figure 1 represents the percentage animal slaughter figure of cattle, goats, sheep, pigs and dogs during the period under review. Three peak periods of high demand were clearly established for cattle in 1999, 2000 and 2002. Similarly goats experienced two peak periods of demand in 1999 and 2000, while the demand for sheep peaked only in 2000, followed by a sharp decrease in the following years. The demand for pigs equally peaked in the first two years of 1999 and 2000, with corresponding drops in 2001 and 2002. The dogs witnessed consistent drops in demand from 1999 up till year 2002.

\section{DISCUSSION}

The analysis of food animals slaughter figures presented here revealed that in terms of number, goats and cattle were the highest slaughtered livestock in Akwa Ibom state during the period under review. This is in agreement with earlier reports by Ogunyemi (1982) and Okoli (2002) that ruminants are the most important animals slaughtered in southeastern states of Nigeria. Equally, the relatively high figures of dogs and pigs reported in this study is in agreement with the findings of Umoh and Ejerugba (1993) that these are delicacies amongst the indigenes of Akwa Ibom.

The thirty-fold increase of slaughter figures in Uyo over the lowest in Mbo LGA shows the purchasing power or culinary habits of the populace in both cases. Most of the animals slaughtered in the state were males. It agrees with earlier reports by Abiola (1996) that male/female ratios of ruminants slaughtered in Oyo state were usually in favour of the males. This has been attributed to the fact that Fulani herdsmen dispose female animals only after their reproductive life has passed (Aladi, 1999; Opara et al., 2002). Annual slaughter figures in this study revealed that most of the animals consumed in the state were in 1999 and 2000 , which later decreased by almost $50 \%$ in subsequent years. This agrees with the reports of Momoh et al. (1998), Afolami and Dipeolu (1998), Nasiru et al. (1998) and Aladi (1999) that there is a declining demand for meat from ruminant livestock as a result of other sources of animal protein. A total revenue of 3.07 million Naira was realized from meat inspection activities in the state during the period of study, giving an average annual income of $\$ 767,717.50$. This figure is higher than that reported by Okoli et al. (2002) who reported a paltry sum of $\$ 30 /$ head of cattle charged for meat inspection in Imo state. However, there is a possibility that higher revenue could accrue from meat inspection services in the state. Some disparities identified in the data submitted point to this. For example, no returns were made for any of the animals in Okobo local government area in 2001. The number of qualified Veterinarians in government employment in most developing countries such as Nigeria is well below the recommended 20,000 veterinary livestock unit (VLU) per Veterinarian (Sanford, 1983; Umali et al., 1994). Veterinary auxiliaries may not be able to accurately report the current state of animals slaughtered to the state headquarters. Apart 
from revenue losses, it is highly probable that none inspected animal food products may become the source for transmission of common zoonotic infection to the unsuspecting public (Acha and Stzytres, 1980; Gracey and Collins, 1992). Similarly, the increasing incidence of tuberculosis reported in most developing countries highlights the need to intensify efforts on meat inspection (Bloom and Murray, 1992; Bell, 1992). This is even more important for Nigeria since it has been reported that butchers operating in the country deliberately remove sick animals before reaching the abattoir and slaughter them at unofficial locations (Aladi, 1999).

The demand for all the animals slaughtered within this period of review fluctuated while that for dogs showed a consistent decreasing trend. This trend may be attributed to the fact that more people are increasingly becoming skeptical about the consumption of dog meat. The younger generations of Akwa Ibomites in recent times are more sophisticated and no longer participate in the consumption of dog meat.

\section{CONCLUSION}

The slaughter figures of food animals in our study shows that cattle, goats and pigs are the major sources of meat in Akwa Ibom state. However, the implication of the findings of this research is that dog meat is a good alternative which could meet the animal protein requirement of the populace especially as the meat is cherished more by the people of the area. There is therefore the need for more research on the consumption of dog meat as a protein source.

\section{REFERENCES}

Abiola, S.S., (1996) Assessment of abattoir and slaughter slab operations in Oyo state, Nigeria. J. Anim. Prod. 23:82.

Acha, P.N. and Stzyfres, B., (1980) Zoonoses and communicable diseases common to man and animal. Scientific publication No. 354 Pan American Health Organization, Washington D.C.

Afolami, C.A. and Dipeolu, M.A., (1998) Average season price pattern for beef in Ogun state. Proceedings of silver anniversary conference of NSAP, Abeokuta, 21-26 March. 3-15.

Aganga, A.O. (1983) Significance of record keeping at abattoirs. Nig. Vet. Jour. 12(1):

Aladi, N.O. (1999) Current trends in the production, handling and sale of meat in Nigeria. B. Agric. Tech. Thesis, Fed. Univ. of Tech., Owerri.

Bloom, B.R. and Murray, C.J.L. (1992) Tuberculosis: Commentary on a re-emergent killer. Science 257: 1055-1064.

Bell, R.T. (1992) Tuberculosis of the 1990's: The quiet public health threat Pa. Med. 95:24-25.

Gracey, J.F. and Collins, D.S. (1992) Meat hygiene. Bailliere Tindall, London.

Gracey, J.F. (1985) Thorton meat hygienist. 7th ed. Bailliere Tindall, London.

Mba, A.U. (1983) Meat production in Nigeria: problems and prospects. In: Nutrition and food policy in Nigeria, National Institute for Policy and Strategic Studies, Jos.

Momoh, S., Anyinde, I.A. and Salawu, K.B. (1998) Animal protein supply: A study of goat marketing in Kwara state. Proceedings of silver anniversary conference of NSAP, Abeokuta, 21-26 March.

Nasiru, M., Sanni, R.M., Abdurham, S. and Egbo, M.C. (1998) Effect of seasonal variations on the sales/volume of ruminants in Bauchi state. Proceedings of the silver anniversary conference of NSAP, Abeokuta, 21-26 March.

Ogundipe, G.A.T., Olukun, S.B. and Esuruoso, G.O. (1989) The development and 
efficiency of the animal health information systems in Nigeria. Preventive Veterinary Medicine, 7:121-135.

Ogunyemi, G. (1982) Meat hygiene in Nigeria. The Vet. Surgeon, 7:23-29.

Ojo, S.A. and Ema, A.N. (1984) Economic losses from bovine liver condemnation in Zaria slaughter houses. National conference on diseases of ruminants, NVRI, Vom, 3-6, October.

Okoli, I.C. Nwokeocha, Joy R., Anyanwu, G.A. and Okeudo, N.J. (2002) Analysis of abattoir records for Imo state, Nigeria from 3995-1999. II: An assessment of the volume and value of slaughter figures returned for the state. Int. J. Env. Hlth Hum. Dev. 3:18-25.

Okoli, I.C. (2001) Analysis of abattoir records for Imo state Nigeria from 1995 to 1999: Disease incidence on cattle, sheep and goats. Int. Jour. Agric. Rural Dev. 2:27-103.

Opara, M.N., Okoli, I.C., Herbert, U. and Adeyemo, O.O., (In press). Ovarian morphology and ostradiol 17 concentration in serum and follicular fluid of zebu cattle slaughtered in Ibadan, Nigeria. Israel J. Vet. Med.

Umoh, B.I. and Ejerugba, P. (1993) Influence of season on the volume of livestock slaughtered in Akwa Ibom state. 18th Ann. Conf. NSAP. Owerri, 21-25 March pp. 130.

Wehke, S.N., Berepubo, N.N. and Ekpenyong, C.E. (1992) Prevalence and implication of inadvertent slaughter of pregnant ruminant in Port Harcourt, Nigeria. Delta Agric. 1:4345.

Table 1. Overall slaughter figures from local government areas in Akwa Ibom state, Nigeria (1999-2002)

\begin{tabular}{lcccccc}
\hline & Cattle (\%) & Goats (\%) & Sheep (\%) & Pigs (\%) & Dogs $(\%)$ & Total (\%) \\
\hline Abak & $2146(5.5)$ & $2301(5.8)$ & $572(4.9)$ & $1717(7.0)$ & $2301(6.3)$ & $9037(6.0)$ \\
Eket & $2001(5.1)$ & $3473(8.8)$ & $766(6.5)$ & $1714(7.0)$ & $1677(4.6)$ & $9631(6.7)$ \\
Ekpe Atai & $157(0.4)$ & $1217(3.1)$ & $413(3.5)$ & $409(1.7)$ & $1075(2.9)$ & $3271(2.3)$ \\
Essien Udim & $869(2.2)$ & $721(1.8)$ & $538(4.6)$ & $1136(4.6)$ & $778(2.1)$ & $4042(2.7)$ \\
Etinan & $610(1.6)$ & $1328(3.4)$ & $496(4.2)$ & $803(3.3)$ & $887(2.4)$ & $4124(2.7)$ \\
Ikono & $214(0.5)$ & $659(1.7)$ & $379(3.2)$ & $1255(5.1)$ & $957(2.6)$ & $3464(2.3)$ \\
Ikot Abasi & $1150(3.0)$ & $1338(3.4)$ & $814(6.9)$ & $1600(6.5)$ & $1736(4.7)$ & $6638(4.4)$ \\
Ikot Ekpene & $3960(10.2)$ & $4199(10.7)$ & $789(6.7)$ & $1796(7.3)$ & $2199(6.0)$ & $12943(8.6)$ \\
Itu & $1110(2.9)$ & $1734(4.4)$ & $470(4.0)$ & $810(3.3)$ & $1485(4.0)$ & $5609(3.7)$ \\
Mkpat Enin & $243(0.6)$ & $1091(2.8)$ & $368(3.1)$ & $704(2.9)$ & $1051(2.9)$ & $3457(2.3)$ \\
Mbo & $11(0.03)$ & $467(1.2)$ & $392(3.3)$ & $376(1.5)$ & $538(1.5)$ & $1784(1.2)$ \\
Nsit Ubium & $196(0.5)$ & $462(1.2)$ & $417(3.5)$ & $865(3.5)$ & $1081(2.9)$ & $3021(2.0)$ \\
Okobo & $12(0.03)$ & $346(0.9)$ & $416(3.5)$ & $428(1.8)$ & $1093(3.0)$ & $2295(1.5)$ \\
Onna & $45(0.1)$ & $287(0.7)$ & $403(3.4)$ & $901(3.7)$ & $800(2.2)$ & $2436(1.6)$ \\
Oron & $1097(2.8)$ & $2158(5.5)$ & $561(4.8)$ & $740(3.0)$ & $1312(3.6)$ & $5868(3.9)$ \\
Ohrukanan & $124(0.3)$ & $660(1.7)$ & $389(3.3)$ & $819(3.3)$ & $668(1.8)$ & $2660(1.8)$ \\
Ukanafun & $162(0.4)$ & $339(0.9)$ & $452(3.8)$ & $506(2.1)$ & $1628(4.4)$ & $3087(2.0)$ \\
Uquo Ibeno & $368(0.9)$ & $580(1.5)$ & $382(3.2)$ & $609(2.5)$ & $1078(2.9)$ & $3017(2.0)$ \\
Oruan & $2645(16.8)$ & $2174(5.5)$ & $608(5.2)$ & $1342(5.5)$ & $3320(9.0)$ & $10089(6.7)$ \\
Uyo & $21826(56.0)$ & $13858(35.2)$ & $2133(18.1)$ & $5919(24.2)$ & $11094(30.2)$ & $54830(36.2)$ \\
Total & $38946(25.7)$ & $39392(26.0)$ & $11758(7.8)$ & $24449(16.2)$ & $36758(24.3)$ & 151303 \\
Mean & 1947.3 & 1969.6 & 587.9 & 1222.5 & 1837.9 & \\
\hline
\end{tabular}




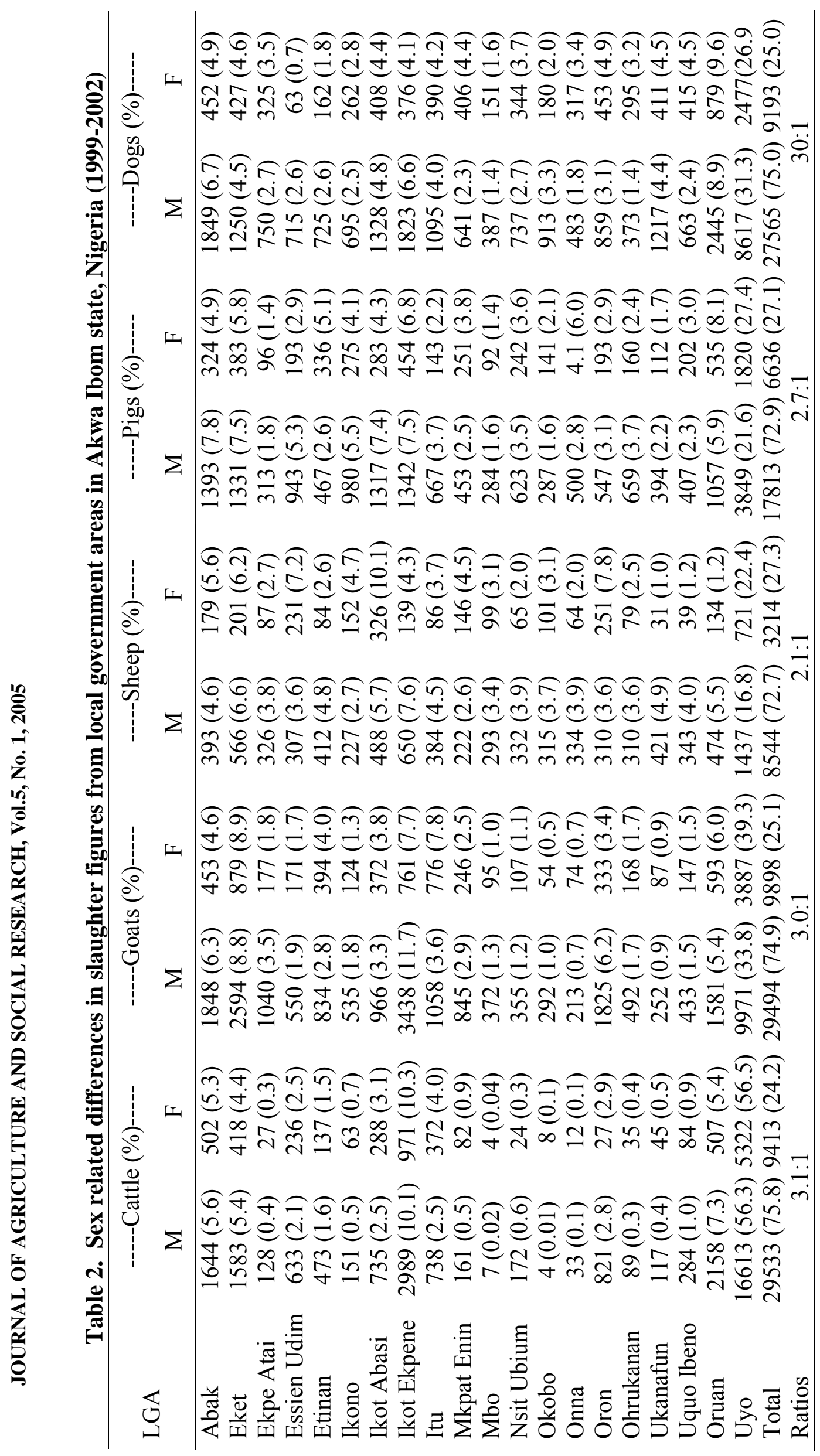




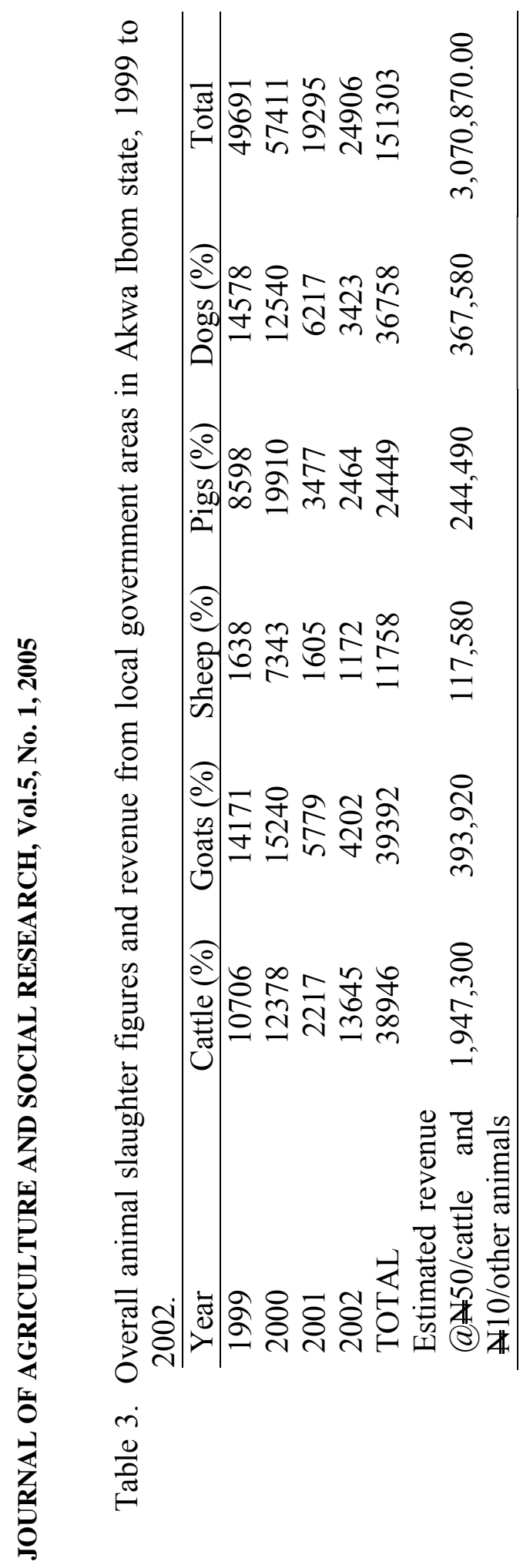




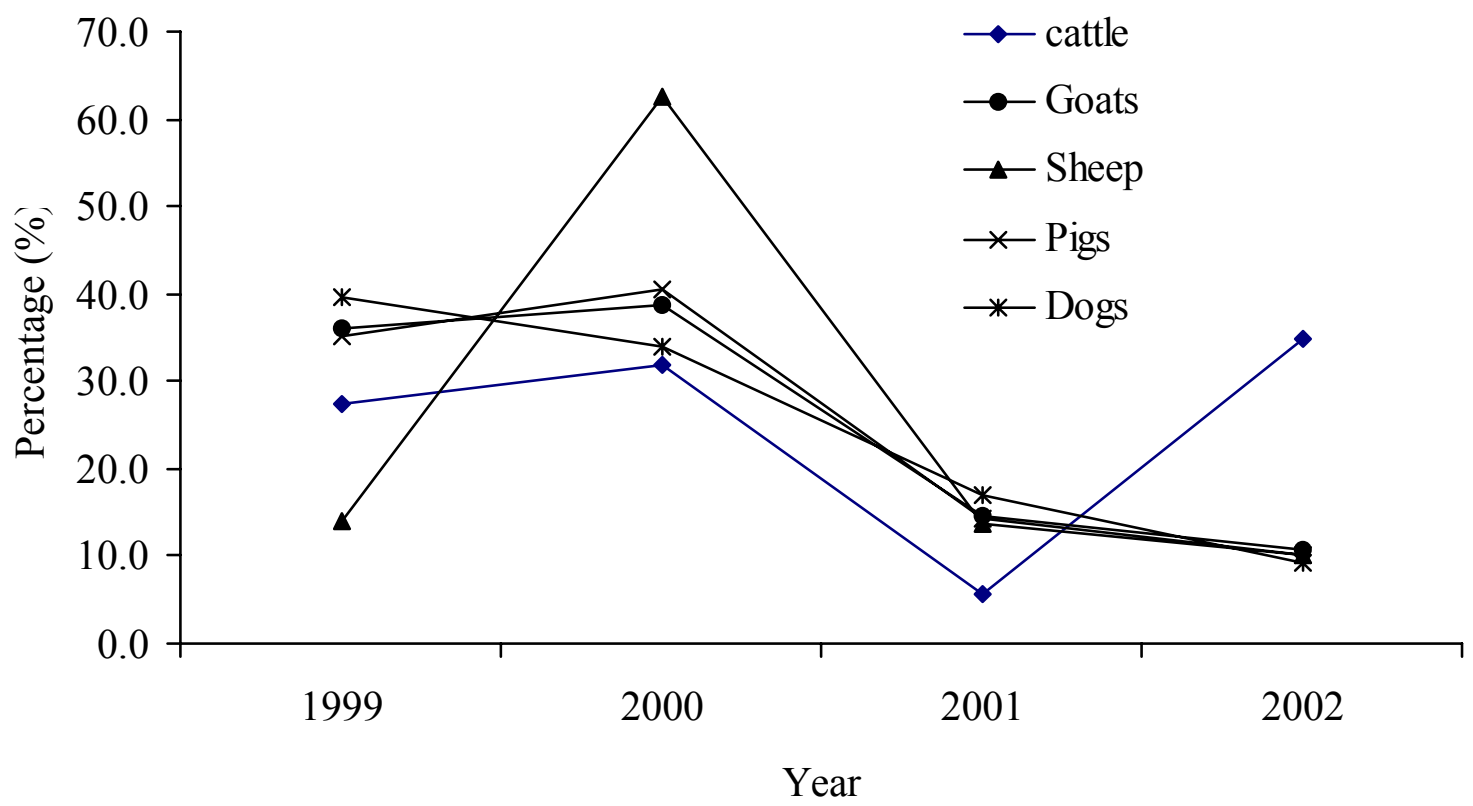

Figure 1. Percentage total slaughter figures of livestock from local government areas in Akwa Ibom state (1999-2002). 